Finance and Economics Discussion Series Divisions of Research \& Statistics and Monetary Affairs Federal Reserve Board, Washington, D.C.

\title{
The Household Spending Response to the 2003 Tax Cut: Evidence from Survey Data
}

\section{Julia Lynn Coronado, Joseph P. Lupton, and Louise M. Sheiner 2005-32}

NOTE: Staff working papers in the Finance and Economics Discussion Series (FEDS) are preliminary materials circulated to stimulate discussion and critical comment. The analysis and conclusions set forth are those of the authors and do not indicate concurrence by other members of the research staff or the Board of Governors. References in publications to the Finance and Economics Discussion Series (other than acknowledgement) should be cleared with the author(s) to protect the tentative character of these papers. 


\title{
The Household Spending Response to the 2003 Tax Cut: Evidence from Survey Data ${ }^{*}$
}

\author{
Julia Lynn Coronado \\ Watson Wyatt Worldwide \\ julia.coronado@watsonwyatt.com \\ Joseph P. Lupton ${ }^{\dagger}$ \\ Federal Reserve Board \\ joseph.p.lupton@frb.gov \\ Louise M. Sheiner \\ Federal Reserve Board \\ louise.m.sheiner@frb.gov
}

July 25, 2005

\begin{abstract}
The Jobs and Growth Tax Relief and Reconciliation Act of 2003 has been described as textbook fiscal stimulus. Using household survey data on the selfreported qualitative response to the tax cuts, we estimate that the boost to aggregate personal consumption expenditures from the child credit rebate and the reduction in withholdings raised the average level of real GDP in the second half of 2003 by 0.2 percent and by 0.3 percent in the first half of 2004 . We also show that households in the survey were well aware of their tax cuts and tended to spend equally out of the child credit rebate and the reduced withholdings, a result that is contrary to the conventional wisdom.
\end{abstract}

JEL Classification: E21, E62, H31

\footnotetext{
* The views expressed are those of the authors and not necessarily those of the Federal Reserve Board or its staff, or of other Watson Wyatt associates. The authors thank Glen Follette, Michael Palumbo, and Matthew Shapiro for helpful comments.

${ }^{\dagger}$ Corresponding author: Federal Reserve Board, 20 ${ }^{\text {th }}$ \& C streets, NW, Washington, DC 20551.
} 


\section{Introduction}

By the end of 2002, the U.S. economy exhibited considerable slack. Although the 2001 recession officially ended in November of that year, the subsequent thirteen months showed little sign of recovery: Roughly 1 million jobs were lost, capacity utilization in the manufacturing sector remained at its trough almost 8 percentage points below its historical average, and real wages and salaries edged down. In the context of this lackluster economic recovery, Congress enacted the Jobs and Growth Tax Relief Reconciliation Act (JGTRRA) in May 2003, an extension of the 2001 Economic Growth and Tax Relief Reconciliation Act (EGTRRA). The EGTRRA and JGTRRA were described as textbook fiscal stimulus. Several studies have examined the impact of the EGTRRA on personal consumption expenditures and the results are mixed (Shapiro and Slemrod, 2003a, 2003b; Agarwal, Liu, and Souleles, 2004; Johnson, Parker and Souleles, 2004; Michel and Rector, 2004). In contrast, the impact of the JGTRRA on household spending remains an unexamined question.

In this paper, we estimate the magnitude of the spending response to the JGTRRA in the year following its enactment, focusing on the effect of the increased child credit and the reduction in withholding taxes. The methodology we use is based on the seminal work of Shapiro and Slemrod (1995, 2003a, 2003b), who used survey data to explicitly ask households how they responded to the 1992 temporary tax reduction and to the 2001 EGTRRA. Our analysis yields three principal findings. First, we perform a series of validation exercises and show that households were well aware of receiving both the child credit rebate that was mailed out in the form of checks in the late summer of 2003 and the boost to disposable income that resulted from decreased withholding taxes. This awareness suggests that an analysis of self-reported responses to the tax cut may indeed lead to valid conclusions. Second, we find no difference between the spending response out of the mailed-out child credit rebate and the reduction in withholding taxes - a finding that runs contrary to the discussion at the time on how to most effectively stimulate spending. Indeed it appears to be higher income households that were more likely to spend the boost to disposable income resulting from the tax cut, suggesting that the economic stimulus did not stem from the short-sighted behavior of rule of thumb consumers. Finally, we estimate marginal propensities to consume out of the child credit rebate and the reduced withholdings and conclude that about a quarter of the increase in disposable income was consumed within the first two quarters of the enacted legislation. Roughly one third of the 
increase in disposable income was consumed in the year following the laws enactment. These results are consistent with the spending response to the EGTRRA reported in Shapiro and Slemrod (2003a, 2003b).

Applied to the aggregate tax cut, the estimated marginal propensities to consume out of the child credit rebate and reduced withholdings imply household spending was boosted by $\$ 10$ billion in the second half of 2003, raising the average level of real GDP by 0.2 percent. In the first half of 2004, household spending was boosted by $\$ 15$ billion, raising the average level of real GDP by 0.3 percent. The actual boost to personal consumption expenditures due to the JGTRRA may have been be larger for several reasons. First, the spending response out of the child credit rebate that we estimate is specific to the advance refund mailed-out in the summer of 2003. However, the increased child credit also reduced 2004 tax payments. Second, the legislation also reduced the alternative minimum tax and the dividend tax rate. These two provisions alone contributed close to 50 percent to the present discounted value of total tax cut and likely further stimulated household spending. Third, the spending response estimated in this paper does not include any feedback effect resulting from the initial boost to aggregate demand.

\section{Tax Policy and Household Spending}

Tax cuts are often portrayed as a quick and effective way to stimulate the economy in the near-term. However, the effectiveness of tax policy largely depends on the degree to which household spending responds to changes in taxes. Unfortunately, with regard to the marginal propensity to consume (MPC) out of a tax cut, economic theory runs the gamut from zero (Barro, 1982) to more than one-half (Campbell and Mankiw, 1989).

According to the permanent income hypothesis (PIH), changes in household spending are proportionate to the present discounted value of revisions to changes in future disposable labor income. One implication of this is that households adjust their spending upon learning about a tax cut rather than at the time of the actual increase in disposable income. Evidence regarding the excess sensitivity of consumption to changes in income is mixed due in large part to the difficulty in identifying exogenous changes to disposable labor income and in determining the permanence of these changes (Browning and Lusardi, 1996). In these two respects, changes to tax policy provide an ideal natural experiment. 
A number of papers have identified excess sensitivity by examining the spending response to arguably predictable changes in disposable income. Wilcox (1989) found that social security recipients increased their spending only at the time they received an increase in benefits rather than when the increase was announced, while Parker (1999) showed that household spending moves up with disposable income at the time in the calendar year when the cumulated annual payroll taxes reach their mandatory cap. Both Wilcox (1990) and Souleles (1999) note that consumer spending tends to jump upon the receipt of pre-determined annual tax refunds.

When changes in tax policy have provided a useful source of identification, researchers have eagerly jumped into the fray. Souleles (2002) examined the timing of the spending response to the Economic Recovery Tax Act of 1981 and concluded that many households only increased their spending when the change in withholdings actually occurred in their paychecks rather than at the time of the enactment of the legislation. More recently, Johnson, Parker and Souleles (2004) showed that households spent the rebate portion of the Economic Growth and Tax Recovery Act of 2001 only at the time of receipt. Although Souleles (2002) reports that liquidity-constraints do not explain excess sensitivity to the 1981 tax cut, Johnson et al. (2004) suggest liquidity-constraints may partially explain the response to the 2001 tax cut. The complement of excess sensitivity is that spending should respond to news about future income. Poterba (1988) examined several fiscal policy changes over the past few decades and found that aggregate consumer spending did not react to the news of these changes in policy, contrary to the PIH.

Much of the literature has focused on the timing rather than the magnitude of the spending response to changes in tax liabilities. Yet the PIH also provides a benchmark for the magnitude of the response to a change in tax policy. Indeed, the potential for both near- and long-term macroeconomic stability depends more on the magnitude of the spending response to tax policy and less on whether spending is excessively sensitive to expected changes in disposable income. In this respect, the success of tax policy is usually measured by the extent to which aggregate demand is stimulated. According to the PIH, only the present discounted value of the change in expected future income is relevant. Consequently, the magnitude of the spending response depends largely on the duration of the change in tax policy. Temporary tax cuts have a smaller 
effect on spending than permanent tax cuts, and tax cuts that are explicitly offset in the near future should have an insignificant effect. ${ }^{1}$

Previous studies of the household spending response to changes in tax policy yield results that are somewhat in line with the PIH in that the response to permanent tax cuts is larger than the response to temporary tax cuts, although there are some exceptions. Also, the responses to temporary tax cuts are somewhat larger than would be expected from the PIH. Blinder (1981) and Poterba (1988) find an initial MPC in the range of 0.16 to 0.24 out of the one-time tax rebate in the 1975 Tax Reduction Act, and an MPC after several quarters far larger than what the PIH would predict. Shapiro and Slemrod (1995) also find evidence of a large response to the to the 1992 tax cut. This result is particularly surprising because the 1992 tax cut was completely offset the following year and this was publicly known at the time of the tax cut.

Despite the relatively large responses to temporary tax cuts in the past, more recent evidence suggests an MPC out of the permanent tax cut in the Economic Recovery Tax Act (ERTA) of 1981 on the order of 0.6 to 0.9 (Souleles, 2002). In contrast to this large response, Shapiro and Slemrod (2003) conclude that the spending response to the 2001 EGTRRA was surprisingly low. There are a few reasons that could explain the difference between these two results. First, the EGTRRA is not a permanent tax cut but is set to expire in 2011, damping the potential spending response. Second, the spending response to a change in tax policy could depend on the economic conditions at the time. Financial conditions were far more accommodative in 2001 than in 1981 and household wealth was more liquid. ${ }^{2}$ Moreover, despite the fall in value of corporate equities in 2001, the ratio of wealth to income remained well above its level in 1981. Combined with a significant degree of financial deregulation over the past few decades, it is quite possible that household discretionary spending was better supported at the time of the 2001 tax cut than at the time of the 1981 tax cut as households were less liquidity constrained.

\section{Household Spending Response to the JGTRRA}

The JGTRRA was primarily a pulling-forward of the tax cuts enacted in the EGTRRA. ${ }^{3}$ The legislation had several provisions. First, the JGTRRA reduced most marginal tax rates above 15

\footnotetext{
${ }^{1}$ In some cases, even tax cuts offset in the distant future could have little effect on aggregate demand (Barro, 1982).

${ }^{2}$ Financial innovations in the past two decades, such as improvements in the pricing of risk and the securitization of loans, have given household far greater access to both secured and unsecured credit.

${ }^{3}$ For the purposes of this paper, the JGTRRA refers only to the individual tax cut provisions.
} 
percent by 2 percentage points and reduced the top marginal tax rate by 3.6 percentage points. These rate reductions had already been included in the EGTRRA, but had been scheduled to go into effect gradually, with a 1 percentage point rate reduction in 2004 and the remainder in 2006. Under the 2003 tax act, these rate reductions all occurred in 2003, and were made retroactive to January 1 of that year. As in the EGTRRA, these tax rate reductions returned to their preEGTRRA levels in 2011. Second, the JGTRRA provided an increase in the 10 percent marginal income tax rate bracket and complete marriage penalty relief, which the EGTRRA did not provide until 2010. Both of these provisions were effective only for 2003 and 2004. Third, the JGTRRA raised the child tax credit from $\$ 600$ per child to \$1,000 per child for 2003 and 2004. Under the EGTRRA, the child credit was scheduled to increase gradually to $\$ 1,000$ by 2010 and then to revert to $\$ 500$ in 2011. The JGTRRA raised it to $\$ 1,000$ for two years, but then had it revert back to its previous schedule. The 2003 portion of the increase ( $\$ 400$ per child) was sent as an advance rebate check to those who had claimed child tax credits on their 2002 tax returns. These checks were sent out in 3 batches - the last week of July and the first two weeks of August. Fourth, the alternative minimum tax exemption was boosted by roughly $\$ 5,000$ for single households and \$10,000 for married households in 2003 and 2004 only. Fifth, dividend income was to be no longer taxed at the marginal income tax rate but rather at the rate equal to the capital gains tax rate. ${ }^{4}$ Given the nature of the survey data examined in this paper, these last two provisions of the JGTRRA are not considered in our empirical analysis.

Table 1 shows the estimated effect of the JGTRRA on real disposable income. Current dollar estimates are reported in parentheses and are based on fiscal year estimates made by the Joint Committee on Taxation at the time of the bill's enactment, which we then convert to quarterly and calendar year values. Current dollar estimates are converted to 2000 dollars using the CPI-U as forecasted in the 2003 Economic Report of the President (ERP). We use a forecasted value of the CPI-U rather than the actual CPI-U to better match household expectations at the time of the tax cut. ${ }^{5}$ As indicated in Table 1, the JGTRRA boosted real disposable income by about \$35 billion in the second half of 2003: $\$ 15$ billion from the rebate for the 2003 child credit—all of which was mailed out in 2003Q3 — and \$20 billion from reduced withholding taxes. Excluding

\footnotetext{
${ }^{4}$ The tax rate on capital gains was reduced to 15 percent for gains previously taxed at a 15 percent or higher rate, and to 5 percent for gains taxed at a lower than 15 percent rate.

${ }^{5}$ The 2003 ERP provides a forecast for the CPI-U through 2005. For the years 2006 to 2010, we assume the CPI-U grows at 2.1 percent, the same rates as forecasted for 2005.
} 
the effect of AMT and dividend tax relief, the JGTRRA boosted real disposable income by $\$ 71$ billion in 2004. Of this increase, $\$ 5$ billion is attributed to the 2004 child credit as it is assumed that some households adjusted their withholdings to take early advantage of the increased credit. The bulk of the 2004 child credit shows up during the 2005 tax season, adding $\$ 11$ billion to real disposable income in 2005. The provisions of the JGTRRA that reduced withholdings added roughly \$66 billion to disposable income in 2004 and are projected to add \$21 billion in 2005. Beyond 2005, the provisions of the JGTRRA increasing the child credit and reducing withholdings are identical to the EGTRRA and so have no marginal effect on disposable income. In contrast, the dividend tax relief provision of the JGTRRA has a sizable estimated impact on disposable income through 2010.

The final column of Table 1 reports the real present discounted value of the individual JGTRRA tax cuts. ${ }^{6}$ In whole, these tax cuts were worth $\$ 275$ billion to households at the time the legislation was passed. Excluding the AMT and dividend tax relief, the JGTRRA tax cuts were worth about half as much. If we assume there exists a representative individual with 45 years of life remaining and a rate of time preference equal to a rate of return to total net wealth that is set to 2 percent, and we further assume that this individual believes the tax cuts will expire as legislated, then a textbook life-cycle model implies a spending response of $\$ 2.3$ billion every quarter over the subsequent 45 years. Of this response, $\$ 0.3$ billion is due to the increased child credit provision and $\$ 0.9$ billion is due to the reduced withholding taxes. The contemporaneous 2003H2 MPC out of the total individual JGTRRA tax cuts, defined at the spending response over this period divided by the tax cut over this period, is $0.13(=2(2.3) / 35)$, according to the PIH. The 2003H2 MPC is 0.03 for the increased child credit and 0.09 for the reduced withholdings. Over the year following the tax cut-2003H2 and 2004H1 — the contemporaneous MPC is 0.11 for the total individual tax cut, and 0.06 and 0.07 for the child tax credit and reduced withholding, respectively.

The present value calculation and the textbook life-cycle model are useful benchmarks. However, as the description of the legislation makes clear, it is difficult to know how the changes affected taxpayer calculations of permanent income. Did taxpayers believe that the temporary provisions of the JGTRRA would actually be allowed to expire? Had taxpayers already reacted

\footnotetext{
${ }^{6}$ Present discount values are computed using the 3-month Treasury bill rate as projected in the 2003 Economic Report of the President. The rate is set to 4 percent for the years 2006 to 2010. This nominal rate is deflated using the projected change in the CPI-U from the 2003 ERP.
} 
to the scheduled future tax cuts enacted by the EGTRRA, in which case the JGTRRA portion of the sum of the two tax cuts would be viewed as a temporary increase in disposable income? Did households respond to the AMT and dividend tax relief even though it would not begin to affect disposable income until 2004? Was the highly-visible mailed out child credit rebate viewed differently than the less visible, but more frequent, reduction in withholdings? Answers to these questions are ultimately an empirical matter.

A simple examination of the aggregate spending data suggests a response to the JGTRRA a substantially larger than implied by the textbook life-cycle model. Average total real personal consumption expenditures (PCE) rose 1.2 percent in the first half of 2003 and then jumped 2.3 percent in the second half of the year. Attributing the entire 1.1 percentage point increase in PCE growth to the JGTRRA implies a spending response of \$37.1 billion and a contemporaneous 2003H2 MPC slightly larger than one. Unfortunately, the boost to disposable income from the JGTRRA coincided with record financial incentives for motor vehicles and a fall in real interest rates to historical lows. While it is likely the JGTRRA contributed to the surge in motor vehicles spending, it is difficult to identify the marginal spending response attributed to the JGTRRA excluding the effect of favorable financial conditions. Moreover, spending in the first half of 2003 was held back by a weak labor market and only modest gains in earnings, boosting the step up in spending growth in the second half of 2003. Consequently, estimating the effect of the JGTRRA on household spending cannot be done using aggregate consumption data alone.

Because the tax cut varied by income and the number of children, household level data on consumer spending could be used to identify the independent effect of the JGTRRA, although it would still be important to control for motor vehicle incentives and falling interest rates. An alternative strategy is to simply ask households how they responded to the JGTRRA, as was done in the Michigan Survey of Consumers in the summer and fall of 2003. A drawback to this methodology is that households may not always do as they say (Bertrand and Mullainathan, 2001). However, Shapiro and Slemrod (2003b) argue the data from the Michigan Survey of Consumers provide a reasonable estimate of the spending response to the EGTRRA when compared to the aggregate data. Moreover, the advantage of this methodology is that it controls for the confounding aggregate factors noted above, as well as much of the observed and unobserved household heterogeneity that affects preferences over the life-cycle. 


\section{The Michigan Survey of Consumers}

Each month the Michigan Survey of Consumers asks a representative sample of about 500 U.S. households a series of questions about their economic situation, as well as their impressions of the macroeconomy. The survey is conducted by telephone. In August, September, and October of 2003, supplemental questions were added to the survey that asked respondents what they did with their tax cut. ${ }^{7}$ The tax cut questions were designed in much the same way as the tax rebate module that was added to the Michigan Survey of Consumers in 2001 regarding the rebate checks sent out as part of the EGTRRA. ${ }^{8}$ The questions distinguish between the rebate portion of the increased child tax credit—mailed out in the form of a check in late July and early August - and the reduction in income tax withholdings that resulted from reductions in marginal tax rates. In particular, the key questions were as follows:

Earlier this year a Federal law was passed that increased the child tax credit and reduced tax rates. Those who qualify for the increased child credit will receive rebate checks worth four hundred dollars for each child. Starting on July first, changes in withholding went into effect resulting in an increase in take home pay for those who qualify for reduced taxes. Thinking about your (family's) financial situation this year, will the [rebate check/increase in take home pay] lead you to mostly to increase spending, mostly to increase saving, mostly to pay off debt, or are you not eligible for [the child tax credit/increase in take home pay]?

The questions use everyday language that map into well-defined economic concepts and are aimed at providing an indication of the overall propensity of households to spend or save in response to the tax cuts. They do not reveal when households actually spent their tax cuts. In particular, the question regarding the child credit rebate does not depend on whether or not the rebate check was actually received. ${ }^{9}$ As a result, the questions do not capture any specific timing that would allow us to shed light on the literature concerning the excess sensitivity of consumption to income. In addition to these questions, households were asked whether they expected their spending response to change "within a year."

Because of the phrasing of the survey questions, interpreting the responses must be done with caution. The child rebate question asks households how they responded to the one-time advance

\footnotetext{
${ }^{7}$ Combining the three waves of the MSC yields a sample of 1,494 households.

${ }^{8}$ See Shapiro and Slemrod (2003a) for a detailed description of the survey design with regard to the tax cuts.

${ }^{9}$ For expositional purposes, the statement "receiving the child credit rebate" should be read as "receiving or expecting to receive the child credit rebate” unless explicitly noted otherwise.
} 
on the 2003 child credit— the rebate "check." There is no mention of the 2004 child credit which would not show up until the 2005 tax season in the form of a larger refund or lower final payments. ${ }^{10}$ It is unclear how this should affect the responses. In general, forward-looking households will smooth a once-a-year payment over the twelve months of the year while more myopic households would consume a larger share. However, forward-looking households should consume a larger share of the rebate check knowing that the increased child credit lasts for two years. As a result, the MPC out of the child credit rebate implied by the responses from the above survey question will be larger than the MPC out of a one-time-only increase in disposable income.

The question regarding the reduction in withholdings simply refers to the "increase in take home pay." Although households were asked to consider their financial situation "this year" in reporting their spending response - effectively the second half of 2003 — it is unclear whether they interpreted the "increase in take home pay" to refer to the effect of the tax cut on disposable income in $2003 \mathrm{H} 2$ or over the life of the tax cut. If forward-looking households interpreted the "increase in take home pay" to refer to the entire life of the tax cut, then they would consume a larger share of the increase in take home pay "this year," knowing that the tax cut extends through 2005. Consequently, depending on how the households interpreted the question, the implied MPC out of the reduction in withholdings may be larger than the MPC out of a onetime-only increase in disposable income.

\section{Survey Validation}

We first examined whether people in the Michigan Survey of Consumers (MSC) were reasonably aware of the tax cut by comparing the data in the MSC to data from the Current Population Survey (CPS). ${ }^{11}$ We use data from the March 2002 supplement to the CPS to determine how the rebate checks and reduced withholdings were distributed across different population groups. The CPS contains information on household adjusted gross income (AGI),

\footnotetext{
${ }^{10}$ One potential reason the question ignores the 2004 child rebate is that it is difficult to disentangle the child credit from the reduced withholdings in 2004 as some households may adjust their withholdings to account for the increased credit.

${ }^{11}$ All the results in this paper that are based on the MSC or CPS are computed using survey weights that provide a representative sample of households. However, the weights had no substantive effect on the results.
} 
the number of children, and the wages of each worker in a household. ${ }^{12}$ Using this information, we calculated whether households would have received a rebate check and whether they would have experienced a change in withholding. Using the changes in the withholding tables, we also calculated how large the change in withholding was likely to have been.

These calculations provide a reasonable approximation to how households were affected by the tax cut provisions. However, the methodology is not perfect. For example, the calculations will not perfectly predict which households received a child credit rebate, as children living with one parent may actually be claimed as dependents on the other parent's tax return (so we would impute a rebate check to the wrong household). Similarly, the changes to individual withholdings are calculated using the previous year's wages, whereas actual changes to withholdings would have been based on wages earned at the time of the survey.

Table 2 compares the percent of households imputed to have received the child credit rebate and a reduction in withholdings with the percent of households in the MSC that reported receiving the tax cuts. The table shows a high degree of awareness of the advance child credit rebate checks. Among all households, 26 percent of respondents in the MSC reported receiving a child credit rebate check compared to 33 percent of all households imputed in the CPS. This small difference disappears when restricting the sample to households with children. The awareness of changes in withholding was smaller. While only 48 percent of households reported a change in their withholdings, the imputations in the CPS suggest 63 percent of households had a reduction in withholdings, a share similar to estimated provided by the Congressional Budget Office. Restricting the sample to households less than age 62 does not eliminate the difference, although both shares increase 10 percentage points.

Table 2 also reports the percent of households receiving a tax cut by income class. Among households with children, there are some distinct differences between the percent of MSC respondents receiving the child credit rebate and the imputed percent from the CPS by income. In both the MSC and the CPS, households in the highest and lowest income categories were less likely to report receiving a check. In general, the relationship between income in the MSC and receipt of the rebate check is weaker than in the CPS. This is most true at the tails of the income distribution where fewer households should have received an advance child credit rebate.

\footnotetext{
${ }^{12}$ AGI is top coded at $\$ 99,999$ in the CPS. For those households with AGI in excess of $\$ 99,999$ we constructed an AGI equal to total family income plus capital gains less non-taxed income like workmen's compensation, social security, and SSI benefits.
} 
One potential explanation for the differences in the receipt of a rebate check by income group between the MSC and the CPS is that households in the MSC were not aware of the income limits for the rebate checks, and that many lower or higher income households anticipated receiving a check when they were not entitled. However, an examination of the differences in responses across the August, September, and October surveys does not show the systematic pattern one might expect in this case - that is, perceived eligibility for the rebate checks did not decline over time. Instead, a more likely explanation is that the household income response in the MSC is a less accurate measure of taxable income than in the CPS, where efforts are made to make sure income measures are accurate. In addition, measurement error is amplified by the smaller cell sizes for the high and low income groups.

As with the child credit, Table 2 also shows a weaker relationship in the MSC between income and a reduction in withholding taxes than indicated in the CPS. The differences are smallest in the largest income groups and largest in the tails of the income distribution, an indication again of potential measurement error. Still, relative to the CPS, there is a 30 percentage point underreporting in the MSC among households with income between \$30,000 and $\$ 75,000$. While almost all households in the CPS in this income class are imputed to have received a reduction in withholding taxes, only 66 percent of the households in the MSC report receiving a reduction.

The comparison of the MSC results and the CPS imputations suggests that the bulk of the population appear to have been aware of receiving the boost to disposable income from the tax cut. Households were quite aware of the rebate checks and were also aware, but less so, of the withholding changes. To the degree that this comparison indicates errors in awareness, they are concentrated in the tails of the income distribution. The fairly high degree of awareness suggests that the examination of self-reported responses to the tax cut is certainly worth pursuing.

\section{Survey Results}

The spending response of households that reported receiving the child credit rebate are shown in Table 3 and the responses for households that reported receiving an increase in take home pay are shown in Table 4. Overall, 27.0 percent of those who reported receiving the child credit rebate said they saved most of it, 49.0 percent said they mostly paid down debt, and 24.0 percent reported they mostly spent the rebate. Among those who said they had received an 
increase in take home pay, 36.8 percent reported saving most of it, 42.5 percent said they mostly paid off debt, and 20.7 percent said they spent most of the increase in pay.

If the tax cuts were viewed as permanent, we would expect forward-looking households to spend most of the increase in disposable income. However, as indicated in Table 1, the JGTRRA was not a permanent tax cut. Indeed, the marginal increase in future disposable income owing to the JGTRRA was smaller than the increase due to the EGTRRA. As a result, the spending response to the JGTRRA should be smaller than the response to the EGTRRA. However, the fraction of households spending most of either the child credit or the reduced withholdings was actually a bit larger than the 21.8 percent of households that reported spending most of the EGTRRA, as reported in Shapiro and Slemrod (2003a).

Tables 3 and 4 present the spending responses by various categories of observable characteristics. In general, the percent of households that reported spending most of the proceeds of their tax cuts rises with income, stock ownership, education, and age. These results are consistent with the findings in Shapiro and Slemrod (2003) and at first blush might appear to contradict the notion that people with low-income and low-education are more likely to face liquidity constraints or follow rule of thumb behavior and thus consume a larger share of income changes. However, these patterns are reversed if we assume households that reported using the tax cut to pay down debt actually boosted spending quickly after paying down their debt. There is some evidence for this behavior in response to the 2001 EGTRRA. Agarwal, Liu and Souleles (2004) show that households who used their tax cut to pay down credit card debt did so only temporarily and that after a one-year period credit card debt was back to the pre-tax cut level, indicating that the tax cut was spent. Focusing only on the percentage of households that reported saving the child credit rebate in Table 3, there is a strong positive relationship between income and the share of households that report saving most of the rebate. As indicated in Table 4, the relationship is weaker for the reduction in withholdings but still positive.

We examine the share of households that reported that they will spend most of the tax cut within a year in order to see if households that paid off debt were expecting to increase their spending in the near future. These results are reported in the final columns of Table 3 and 4 and do not support the hypothesis that most of the households that pay off debt will quickly increase spending. This is consistent with the results in Shapiro and Slemrod (2003b) who use the small 
panel component of the MSC to show that households did not change their spending response roughly six months later.

\section{Differences between checks and withholding}

As noted above, one difference between a tax cut delivered through a one-time paymentsuch as the mail-out rebate of the 2003 increase in the child credit—and a tax cut spread out over time — such as the provisions of the JGTRRA that reduced withholdings — is that people may be more likely to notice a one-time payment opposed to a more gradual reduction in withholdings. In this section, we examine the differences in spending responses for those who report receiving both the rebate check and the reduction in withholding. In particular, we examine whether households were more likely to report spending most of their rebate checks than they were their reduced withholding.

The MCS sample contains 306 households that reported receiving both a child credit rebate check and reduced withholdings. Table 5 shows the spending responses of these households. Overall, households seem to have made little distinction between the rebate checks and their reduced withholdings - with roughly two-thirds planning to use the child credit rebate check and the increase in take-home pay in an identical manner (spend, save, or pay down debt). Even over the course of a year there is little difference in the spending plans for the child credit rebate and the reduction in withholdings. As indicated in Tables 3 and 4, the share of households planning on spending most of their tax cut increases by about 5 to 10 percentage points when the time horizon is expanded from the second half of 2003 to a year. Table 5 shows that the same is true for households that received both the increased child credit and the reduced withholdings, with the percent of households expecting to spend most of the income from both tax cut provisions increasing from 11.6 percent over $2003 \mathrm{H} 2$ to 17.8 percent over the subsequent year.

The reduction in withholdings is a tax cut that increases the take-home pay of every paycheck between 2003 and 2005, while the child credit rebate check is a one-time payment, paid out in third quarter of 2003. ${ }^{13}$ Households that prefer to smooth their consumption should have saved most of the child credit rebate and spread it over the year and spent a larger share of the reduced withholdings because it was already smoothed. The results in Tables 3, 4 and 5 are

\footnotetext{
${ }^{13}$ As noted above, the JGTRRA also includes an increase in the 2004 child credit but this was not referenced in the survey question.
} 
somewhat surprising because the spending response to the child rebate is roughly as large as the spending response to the reduction in withholdings, implying that the highly visible form in which the child credit rebate was paid out had an effect. However, most analysts at the time expected the child credit rebate to provide an immediate boost to spending that would be greater than the stimulus from the reduced withholdings. Based on the MSC data, this does not appear to have happened.

Unfortunately, it is difficult to make any strong conclusions about consumption smoothing behavior because we do not know the types of expenditures that were financed with the tax cut. For example, the consumption induced by the rebate check may have been smoothed the same as the consumption induced by the reduction in withholdings if households were more likely to spend the rebate check on a durable good, such as a car or television (Mankiw, 1982). ${ }^{14}$ To determine if the type of consumption goods financed by the child credit rebate differed substantially from those financed by the reduced withholdings, we examined the buying attitudes provided in the MSC.

As indicated in Table 6, 72.2 percent of all households claimed it was a "good time" to buy a car, and 68.5 percent claimed it was a "good time” to buy a major household appliance such as furniture, a refrigerator, a stove, or a television. Receiving either the child credit rebate or a reduction in withholdings (or both) does not seem to have changed people's feelings about buying a car or major appliance. However, not surprisingly, households that reported spending most of their child credit rebate felt on average that it was a better time to buy a car than did all households on average. Households that reported spending most of their reduced withholdings felt it was a better time than the average household to purchase both cars as well as other major appliances.

Comparing the buying attitudes of households that spent most of their child credit rebate to those that spent most of their reduced withholdings provides little support for the hypothesis that the child credit rebate was more likely to be used to purchase a durable good. Indeed, the opposite hypothesis cannot be rejected. While 76.8 percent of households that spent most of their child credit rebate felt it was a good time to buy a car and 65.9 percent felt it was a good time to buy a major appliance, 82.2 percent of households that spent most of their reduced

\footnotetext{
${ }^{14}$ Many retailers ran advertisements in the summer of 2003 encouraging households to spend their rebate checks. Indeed, retailers such as Home Depot, Sears and Wal-Mart advised consumers to cash their rebate check at the store while making a purchase. Big-ticket durable items were highly promoted during this advertising blitz.
} 
withholdings claimed it was a good time to buy a car and 77.9 percent were optimistic about purchasing a major appliance. Neither of these differences can be rejected at a 10 percent level of significance.

The bottom two rows of Table 6 control for differences across households receiving the child credit rebate, which favored lower to middle income households, and households that received reduced withholdings, which favored middle to upper income households. On average, households that only received a reduction in withholdings had about $\$ 30,000$ more income than households that only received a child credit rebate. Restricting the sample to households that received both tax cut provisions, 82.5 percent of those that spent most of their child rebate felt it was a good time to buy a car and 62.5 percent felt it was a good time to buy a major appliance. By comparison, a smaller 73.8 percent of those that spent most of their reduced withholdings were optimistic about purchasing a car while a larger 75.3 percent were upbeat about buying a major appliance. Both of these differences are rejected at a 10 percent level of significance, suggesting the child credit rebates were no more likely than the reduced withholdings to have been smoothed in terms of consumption by way of the purchase of durable goods.

\section{Estimating the Marginal Propensity to Consume}

The advantage of the MSC data compared to data on consumer expenditures is that it relates to the change in household spending given the tax cuts compared to what households believed their spending would have been in the absence of the tax cuts. Consequently, the marginal propensity to consume can be examined in a way that cannot be done with expenditure data. More formally, we consider a model of the household spending response $S_{i}$ to the tax cut $\tau_{i}$ that allows for both observed and unobserved heterogeneity in the MPC:

$$
S_{i}=\mu\left(\gamma^{\prime} X_{i}+\eta_{i}\right) \tau_{i},
$$

where $\mu($.$) is an approximation to household i$ 's MPC out of the tax cut with $0<\mu(z)<1$ and $\partial \mu(z) / \partial z>0$ for all $z$. The MPC varies across households by an observable vector of household characteristics, $X_{i}$, and an unobservable scaler $\eta_{i}$, which is known to the household and is independently and identically distributed across households with mean zero. ${ }^{15}$

\footnotetext{
${ }^{15}$ Because the purpose of this paper is not to estimate underlying parameters of the household consumption function, this MPC is general enough that it can be motivated by almost any model of consumer behavior.
} 
If the MSC measured each household's spending response, the MPC would simply be given by the ratio of this response to an estimate of their tax cut, and the aggregate MPC would immediately follow. Unfortunately, the spending response is unobserved. Rather, the survey instrument measures only whether the tax cut led households to "mostly increase spending,", "mostly increase saving," or to "mostly pay off debt." That is, $S_{i}$ can be thought of as a latent variable.

Let $I_{i}=1$ if a household claims to have mostly increased their spending in response to the tax cut, implying $S_{i}>\lambda \tau_{i}$ for some $\lambda$ to be determined, and $I_{i}=0$ otherwise. The empirical model then follows from the definition of the indicator variable and (1):

$$
\begin{aligned}
\operatorname{Pr}\left(I_{i}=1 \mid X_{i}, \tau_{i}, \lambda\right) & =\operatorname{Pr}\left(S_{i}>\lambda \tau_{i}\right) \\
& =\operatorname{Pr}\left(\mu\left(\gamma X_{i}+\eta_{i}\right)>\lambda\right) \\
& =\operatorname{Pr}\left(\eta_{i}<\gamma X_{i}-\mu^{-1}(\lambda)\right),
\end{aligned}
$$

where the last equality follows from the assumption that $\mu($.$) is monotonically increasing and \eta_{i}$ is symmetric around zero.

The marginal propensity to consume can be identified by maximum likelihood using (2), given the distribution of $\eta$, a function $\mu($.$) , and a value for \lambda$. We assume $\eta \sim N(0,1)$ and $\mu($.$) is a cumulative standard normal function. The value for \lambda$ is related to the survey question. Typically, the term "mostly" would refer to one-half and so $\lambda=1 / 2$. However, the respondents were given three choices in the survey: mostly increase spending, mostly increase saving, or mostly pay off debt. As a result, some households could have "mostly spent" the tax cut while still spending less than one-half of it. The smallest share of the tax cut a household could spend while still spending a plurality is one-third, suggesting $1 / 3 \leq \lambda \leq 1 / 2$. We split this difference and set $\lambda=5 / 12$, although our results for the effect of the tax cut on aggregate personal consumption expenditures are not greatly affected by setting $\lambda$ equal to $1 / 3$ or $1 / 2$.

Table 7 reports the results from estimating (2) under the above assumptions controlling for demographic and financial characteristics. Consistent with the life-cycle hypothesis, households headed by older individuals appear to have consumed a larger share of both the child credit rebate and the reduction in withholdings, both contemporaneously (2003H2) and over the subsequent year (through 2004H1). In contrast to the univariate relationship noted in Tables 3 
and 4, there is no significant relationship between asset ownership and the spending response out of the child credit rebate after controlling for age and income. With regard to the reduced withholdings, although stock ownership boosted the spending response by one-third on average, all else equal, this is more than offset by home ownership, which appears to have reduced the spending response out of the reduction in withholdings by almost one-half on average. ${ }^{16}$ Consequently, there is little support for the hypothesis that liquidity constraints boosted the MPC’s of low wealth households.

The relationship between income and the contemporaneous MPC out of both tax cuts is insignificant for incomes below \$75,000. However, households with income between \$75,000 and \$100,000 have an MPC out of the reduction in withholdings that is 23 percent larger than households with income less than $\$ 30,000$. Households with income greater than $\$ 100,000$ have an MPC out the reduction in withholdings that is 38 percent larger. This positive relationship is at odds with the conventional wisdom that households with higher income tend to have a higher propensity to save (Dynan, Skinner and Zeldes, 2004). Even after controlling for education as a proxy for permanent income, the estimated relationship between income and the MPC is positive. ${ }^{17}$ The MSC also asks households about whether they expect their earnings growth to keep pace with the rate of inflation. Not surprisingly, households that were more optimistic about their future real income growth spent roughly one-third more of both their tax cuts than the average household. In general, the relationship between the MPC and income does not change when the spending response is extended to the entire year following the tax cut.

We next examine the distribution of the estimated MPC across households. Without observing $\eta$, we can only consider the expected value of a household's MPC, which we estimate numerically. ${ }^{18}$ The last two rows of Table 7 report the mean and standard deviation of the expected MPC out of the child credit rebate and the reduced withholdings. There is little difference between the mean MPC out of the child credit rebate and the mean MPC out of the reduction in withholdings. In both cases, the average household expected to spend or had spent roughly one-quarter of both tax cuts in the second half of 2003. In the year following the tax cut,

\footnotetext{
${ }^{16}$ All marginal effects are computed by taking the difference between the imputed MPC with the dummy variable in question set to 1 less the imputed MPC with the dummy variable set to 0 . All other variables are set to the sample median, and the unobserved component $\eta$ is set to zero.

${ }^{17}$ These results are not shown in the Table 7.

${ }^{18}$ We estimate $E\left[\mu\left(\gamma^{\prime} X_{i}+\eta_{i}\right)\right]$ for each household by simulating $\mu\left(\gamma^{\prime} X_{i}+\eta_{i}\right)$ with 1,000 draws from a standard normal and taking its mean.
} 
the average household expected to spend roughly one-third of the child credit rebate and the reduced withholdings. However, the step-up in spending out of the reduced withholdings was somewhat larger than the step-up in spending out of the child credit rebate, consistent with the reduced withholdings affecting permanent income more so than the one-time rebate check.

The average MPC’s in Table 7 are similar to the share of households reporting to have mostly increased their spending in response to the tax cuts, as indicated in Tables 3 and 4. However, because the estimated MPC's are partly determined by the identifying assumptions for the distribution of $\eta$, the function $\mu($.$) , and the value for \lambda$, the similarity in the results was by no means inevitable. Indeed, a distribution of $\eta$ with less mass in its tails, or a function $\mu($.) and value $\lambda$ that generates a larger value for $\mu^{-1}(\lambda)$ would yield a larger estimated MPC. To the extent that the identifying assumptions are plausible, the results in Table 7 provide a reasonable estimate of each household's MPC out of the tax cut. In contrast, the share of households reporting to have spent "most" of the tax cut cannot be interpreted as an MPC either for an individual household or for the aggregate.

\section{Aggregate Spending Response}

In terms of dollar value, the child credit increase favored middle income households while the reduced withholdings largely favored higher income households. In addition, the results in Table 7 suggest households with more income spent a larger share of their tax cut.

Consequently, the aggregate spending response cannot be obtained by simply applying the mean MPC reported in Table 7 to the aggregate tax cut. To compute the aggregate spending response, we first estimate the mean of the MPC's by income class using the empirical model described above. ${ }^{19}$ We then compute the share of the aggregate tax cut by income class using an imputed tax cut from the March supplement of the 2002 CPS. The spending response within each income class is then computed as the product of the MPC and tax cut. The aggregate spending response is the sum across income classes and the aggregate MPC is defined as the ratio of the aggregate spending response to the aggregate tax cut. These results are reported in Table 8.

The child credit rebate boosted total real spending by an estimated $\$ 4$ billion dollars in the second half of 2003. The spending response was largest among households earning between

\footnotetext{
${ }^{19}$ These estimates are interpreted only as descriptive of the spending response within income groups.
} 
$\$ 30,000$ and $\$ 75,000$ per year. This reflects the fact these households received the largest share of the child credit rebate and not that they had a higher MPC, which was smaller than that of households with higher income. Not surprisingly, the aggregate spending response to the onetime child credit rebate did not increase much beyond 2003, only increasing $\$ 0.7$ billion in the first half of 2004 as indicated by the difference between the bottom and top panels of Table 8 .

The reduced withholdings boosted total real spending by about $\$ 6$ billion in the second half of 2003, as indicated in Table 8. Unlike the response to the child credit rebate, the spending response to the reduced withholdings is largely concentrated among households with annual income greater than $\$ 100,000$, reflecting both a larger estimated MPC and the fact that these households received $2 / 3$ of the withholdings reduction. The spending response to the reduced withholdings rose to about $\$ 14$ billion in the first half of 2004 and was again, largely concentrated among high income households. This skewed distribution of the tax cut across income groups yields an aggregate MPC that is about 20 percent larger than the mean of the MPC's across all households.

The last three columns of Table 8 combine the responses to the child credit rebate and the reduced withholdings. Total real spending was boosted by $\$ 10$ billion in the second half of 2003 implying an aggregate MPC of 0.28 , and by $\$ 15$ billion in the first half of 2004 implying a cumulative aggregate MPC of 0.36. In general, the spending response was concentrated among higher income households with about one-half of the total increase in spending attributed to households earning more than $\$ 100,000$.

\section{Conclusion}

Using household survey data on the self-reported qualitative response to the tax cuts enacted as part of the Jobs and Growth Tax Relief and Reconciliation Act of 2003, we estimate that the aggregate personal consumption expenditures was boosted in the second half of 2003 by $\$ 9.7$ billion from the child credit rebate and the reduction in withholdings. Depending on how households interpreted the survey question, the actual boost to personal consumption expenditures may have been larger than we estimate. In particular, the survey does not ask about the response to the AMT and dividend tax relief, which combine to make up roughly one-half of the total value of the tax cut. Nor does our estimate include any potential feedback effect from the initial increase in output. Indeed, this could partially explain why the estimated spending 
response is roughly 1/3 as large as the actual step-up in aggregate real personal consumption expenditures over that time period. In contrast, the estimated spending response is about two times larger than the response implied by the permanent income hypothesis. This discrepancy does not appear to be a result of liquidity constraints: We find no relationship between the contemporaneous MPC out of the tax cuts and household asset holdings and a positive relationship with income.

We estimate the JGTRRA boosted aggregate personal consumption expenditures by $\$ 15$ billion in the first half of 2004. This is in contrast to a step-down in the growth of actual aggregate personal consumption expenditures in 2004H1. However, it is difficult to disentangle the continuing effects of the JGTRRA in early 2004 from the effects of the near-record jump in oil prices that occurred at that time.

Contrary to conventional wisdom, there is little evidence that households spent a larger share of their child credit rebate than of their reduced withholdings. However, this result is also inconsistent with economic theory, which suggests households should have spent a smaller share of the child credit rebate. The marginal propensity to consume was about the same for both tax cuts and equal to roughly $1 / 4$. We also find no evidence indicating that the rebate check was more likely to be spent on durable goods. 


\section{References}

Agarwal, Sumit, Liu, Chunlin, and Souleles, Nicholas S. "The Response of Consumer Spending and Debt to Tax Rebates -- Evidence from Consumer Credit Data.” The Wharton School working paper, 2004.

Barro, Robert J. "Are Government Bonds Net Wealth." Journal of Political Economy, 1974, 82 (6), 1095-1117.

Bertrand, Marianne, Mullainathan, Sendhil. "Do People Mean What They Say? Implications for Subjective Survey Data." American Economic Review, 2001, 91 (2), 67-72.

Browning, Martin, Lusardi, Annamaria. "Household Saving: Micro Theories and Micro Facts." Journal of Economic Literature, 1996, 34 1797-1855.

Campbell, John Y., Mankiw, N. Gregory. "Consumption, Income, and Interest Rates: Reinterpreting the Time Series Evidence," Blanchard, Olivier J., Fischer, Stanely, NBER Macroeconomics Annual 1989. Cambridge, MA: MIT Press, 1989, 185-216.

Dynan, Karen E., Skinner, Jonathan, Zeldes, Stephen P. "Do the Rich Save More?" Journal of Political Economy, 2004, 112 (2), 397-444.

Johnson, David S., Parker, Jonathan A., Souleles, Nicholas S. "The Response of Consumer Spending to the Randomized Income Tax Rebates of 2001." The Wharton School working paper, February 2004.

Michel, Norbert J. and Rector, Ralph A. "Was the 2001 Tax Rebate Effective Stimulus Policy? Using the Consumer Expenditure Survey to Test Whether Consumers Spent Their Rebate Checks.” Heritage Foundation working paper, June 2004.

Mankiw, N. Gregory. Press briefing, Washington, D.C., Council of Economic Advisers, February 9, 2004.

. "Hall's Consumption Hypothesis and Durable Goods.” Journal of Monetary Economics, 1982, 10, 181-196.

Modigliani, Franco and Steindel, Charles. "Is a Tax Rebate an Effective Tool for Stabilization Policy?" Brookings Papers on Economic Activity, 1977, 1977 (1), 175-209.

Parker, Jonathan A. "The Reaction of Household Consumption to Predictable Changes in Payroll Tax Rates." American Economic Review, 1999, 89 (4), 413-418.

Poterba, James M. "Are Consumers Forward Looking? Evidence from Fiscal Experiments." American Economic Review, 1988, 78 (2), 413-418.

Shapiro, Matthew D., Slemrod, Joel. "Consumer Response to Tax Rebates." American Economic Review, 2003, 93 (1), 381-396.

. "Consumer Response to the Timing of Income: Evidence from a Change in Tax Withholding." American Economic Review, 1995, 85 (1), 274-283.

. "Did the 2001 Tax Rebate Stimulate Spending? Evidence from Taxpayer Surveys," Poterba, James, Tax Policy and the Economy. Cambridge: MIT Press, 2003.

Souleles, Nicholas S. "Consumer Response to the Reagan Tax Cuts." Journal of Public Economics, 2002, 85, 99-120.

. "The Response of Household Consumption to Income Tax Refunds." American Economic Review, 1999, 89 (4), 947-958.

Tax Policy Center. "Conference Agreement on the Jobs and Growth Tax Relief Reconciliation Act of 2003: Distribution of Income Tax Change by AGI Class, 2003.” Table T03-0107, May 22, 2003.

Wilcox, David W. Social Security Benefits. "Consumption Expenditures, and the Life-Cycle Hypothesis.” Journal of Political Economy, 1989, 97(2), 288-304.

Wilcox, David W. "Income Tax Refunds and the Timing of Consumption Expenditure." Federal Reserve Board Working Paper, 1990. 
Table 1: Effect of the JGTRRA on Real Disposable Income (Billions of 2000 \$)

\begin{tabular}{lccccc}
\hline \hline & $2003 \mathrm{H} 2$ & 2004 & 2005 & $2006-2010$ & PDV \\
\hline Total & 35 & 101 & 58 & 91 & 275 \\
& $(37)$ & $(110)$ & $(65)$ & $(107)$ & \\
...Increased Child Credit & 15 & 5 & 11 & 0 & 30 \\
& $(16)$ & $(5)$ & $(12)$ & $(0)$ & \\
...Lowered Withholdings & 20 & 66 & 21 & 0 & 106 \\
& $(21)$ & $(72)$ & $(24)$ & $(0)$ & \\
...AMT \& Dividend Tax Relief & 0 & 30 & 26 & 91 & 139 \\
& $(0)$ & $(33)$ & $(29)$ & $(107)$ & \\
\hline
\end{tabular}

The estimated magnitude of the tax cut comes from the Joint Committee on Taxation at the time the JGTRRA was enacted. Real values are computed using the forecasted CPI-U from the February, 2003 Economic Report of the President (ERP), converted to 2000 dollars. Nominal values are in parentheses. The 2006-2010 column reports the sum of the tax cut over those years. The final column reports the real present discounted value of the tax cut as of 2003Q3 using the projected rate of the 3-month Treasury bill from the February, 2003 ERP less the projected percent change in the CPI-U (beyond 2005, the real interest is set to 2 percent). 
Table 2: Percent of Households Receiving Tax Cut

\begin{tabular}{|c|c|c|c|c|}
\hline & \multicolumn{2}{|c|}{ Child Credit Rebate } & \multicolumn{2}{|c|}{ Reduced Withholding Tax } \\
\hline & MSC & CPS & MSC & CPS \\
\hline \multirow[t]{2}{*}{ All Households } & 26 & 33 & 48 & 63 \\
\hline & \multicolumn{2}{|c|}{...with children } & \multicolumn{2}{|c|}{...age less than 62} \\
\hline $\begin{array}{l}\text { All Households... } \\
\text { Income }(\$ 1,000)\end{array}$ & 68 & 69 & 58 & 73 \\
\hline Less than 15 & 28 & 1 & 28 & 1 \\
\hline 15 to 30 & 57 & 55 & 41 & 55 \\
\hline 30 to 75 & 76 & 96 & 66 & 96 \\
\hline 75 to 150 & 78 & 84 & 64 & 84 \\
\hline 150 to 250 & 68 & 4 & 65 & 4 \\
\hline Greater than 250 & 57 & 0 & 75 & 0 \\
\hline
\end{tabular}

Responses from the Michigan Survey of Consumers (MSC) cover the 2003 August, September and October surveys and are weighted use the MSC provided population weights. Responses from the Current Population Survey (CPS) are imputed using the March 2002 Supplement. 
Table 3: Responses to the Child Credit Rebate

\begin{tabular}{|c|c|c|c|c|c|c|}
\hline & \multirow[b]{2}{*}{$\mathrm{N}$} & \multirow{2}{*}{$\begin{array}{l}\text { Percent } \\
\text { Eligible }\end{array}$} & \multicolumn{4}{|c|}{ Response (percent) } \\
\hline & & & Save & $\begin{array}{c}\text { Reduce } \\
\text { Debt }\end{array}$ & Spend & $\begin{array}{c}\text { Spend within } \\
\text { a Year }\end{array}$ \\
\hline All Eligible Households & 386 & 100.0 & 27.0 & 49.0 & 24.0 & 30.1 \\
\hline \multicolumn{7}{|l|}{ Income $(\$ 1,000)$} \\
\hline Less than 30 & 80 & 24.4 & 17.6 & 62.6 & 19.8 & 25.5 \\
\hline 30 to 75 & 165 & 44.6 & 25.5 & 53.1 & 21.4 & 29.4 \\
\hline 750 to 100 & 71 & 17.8 & 34.7 & 34.0 & 31.3 & 36.4 \\
\hline Greater than 100 & 51 & 13.2 & 45.6 & 17.5 & 36.8 & 36.8 \\
\hline \multicolumn{7}{|l|}{ Corporate Equities } \\
\hline Don't own & 132 & 35.8 & 23.2 & 57.6 & 19.2 & 25.3 \\
\hline Own & 254 & 64.2 & 29.2 & 44.2 & 26.6 & 32.8 \\
\hline \multicolumn{7}{|l|}{ Education of Head } \\
\hline No high school degree & 24 & 6.7 & 28.6 & 62.9 & 8.6 & 19.0 \\
\hline High school degree & 105 & 29.1 & 23.8 & 52.3 & 23.8 & 33.3 \\
\hline Some College & 91 & 23.3 & 23.7 & 53.7 & 22.6 & 30.3 \\
\hline College degree & 166 & 40.8 & 31.0 & 41.7 & 27.4 & 29.6 \\
\hline \multicolumn{7}{|l|}{ Age of Head } \\
\hline Less than 45 & 301 & 81.0 & 27.8 & 50.3 & 22.0 & 27.9 \\
\hline 45 to 62 & 80 & 17.5 & 26.1 & 41.9 & 32.0 & 39.7 \\
\hline Greater than 62 & 4 & 1.4 & 0.0 & 57.1 & 42.9 & 42.9 \\
\hline
\end{tabular}

Responses from the Michigan Survey of Consumers (MSC) cover the 2003 August, September and October surveys and are weighted use the MSC provided population weights. Cell counts did not sum to total due to missing values. 
Table 4: Responses to the Reduced Withholding Tax

\begin{tabular}{|c|c|c|c|c|c|c|}
\hline & \multirow[b]{2}{*}{$\mathrm{N}$} & \multirow[b]{2}{*}{$\begin{array}{l}\text { Percent } \\
\text { Eligible }\end{array}$} & \multicolumn{4}{|c|}{ Response (percent) } \\
\hline & & & Save & $\begin{array}{l}\text { Reduce } \\
\text { Debt }\end{array}$ & Spend & $\begin{array}{c}\text { Spend within } \\
\text { a Year }\end{array}$ \\
\hline All Eligible Households & 730 & 100.0 & 36.8 & 42.5 & 20.7 & 32.4 \\
\hline \multicolumn{7}{|l|}{ Income $(\$ 1,000)$} \\
\hline Less than 30 & 129 & 21.3 & 30.7 & 53.7 & 15.5 & 25.0 \\
\hline 30 to 75 & 333 & 47.1 & 36.4 & 43.9 & 19.7 & 32.3 \\
\hline 750 to 100 & 107 & 15.0 & 42.4 & 33.6 & 24.1 & 35.8 \\
\hline Greater than 100 & 116 & 16.6 & 34.2 & 30.2 & 35.6 & 51.7 \\
\hline \multicolumn{7}{|l|}{ Corporate Equities } \\
\hline Don't own & 224 & 32.1 & 32.9 & 51.7 & 15.3 & 27.4 \\
\hline Own & 506 & 67.9 & 38.7 & 38.2 & 23.2 & 34.7 \\
\hline \multicolumn{7}{|l|}{ Education of Head } \\
\hline No high school degree & 25 & 3.5 & 27.5 & 54.9 & 17.6 & 27.4 \\
\hline High school degree & 171 & 24.5 & 35.0 & 47.7 & 17.2 & 30.7 \\
\hline Some College & 174 & 24.3 & 33.5 & 45.2 & 21.3 & 36.8 \\
\hline College degree & 360 & 47.7 & 40.1 & 37.5 & 22.4 & 31.4 \\
\hline \multicolumn{7}{|l|}{ Age of Head } \\
\hline Less than 45 & 433 & 63.8 & 37.7 & 44.0 & 18.4 & 32.5 \\
\hline 45 to 62 & 248 & 29.1 & 33.5 & 44.3 & 22.3 & 30.2 \\
\hline Greater than 62 & 45 & 6.7 & 43.0 & 22.3 & 34.7 & 40.4 \\
\hline
\end{tabular}

Responses from the Michigan Survey of Consumers (MSC) cover the 2003 August, September and October surveys and are weighted use the MSC provided population weights. Cell counts did not sum to total due to missing values. 
Table 5: Percent Response Among Households Receiving Both Tax Cuts

\begin{tabular}{lrrrrr}
\hline \hline & \multicolumn{5}{c}{ Reduced Withholding Tax } \\
\cline { 2 - 5 } & Save & $\begin{array}{c}\text { Reduce } \\
\text { debt }\end{array}$ & Spend & Total & $\begin{array}{c}\text { Spend within } \\
\text { a year }\end{array}$ \\
Child Credit Rebate & 22.0 & 5.0 & 3.8 & 30.8 & 8.3 \\
Save & 10.6 & 31.9 & 5.2 & 47.8 & 11.9 \\
Reduce debt & 4.5 & 5.3 & 11.6 & 21.4 & 12.7 \\
Spend & 37.1 & 42.3 & 20.6 & 100.0 & 32.9 \\
Total & 5.8 & 8.1 & 13.9 & 27.9 & 17.8 \\
\hline Spend within a year & &
\end{tabular}

Responses from the Michigan Survey of Consumers (MSC) cover the 2003 August,

September and October surveys and are weighted use the MSC provided population weights. 
Table 6: Households Claiming "Good Time" to Buy

\begin{tabular}{|c|c|c|c|c|}
\hline & \multicolumn{2}{|c|}{ Car } & \multicolumn{2}{|c|}{ Major Appliance } \\
\hline & Percent & $p$-value & Percent & $p$-value \\
\hline All Households & 72.2 & & 68.5 & \\
\hline \multicolumn{5}{|l|}{ Received... } \\
\hline Child Credit Rebate & 73.8 & \multirow{2}{*}{0.32} & 66.4 & \multirow{2}{*}{0.63} \\
\hline Reduced Withholding Tax & 74.2 & & 68.6 & \\
\hline \multicolumn{5}{|l|}{ Received and spent most of... } \\
\hline Child Credit Rebate & 76.8 & \multirow{2}{*}{0.04} & 65.9 & \multirow{2}{*}{0.06} \\
\hline Reduced Withholding Tax & 82.0 & & 77.9 & \\
\hline \multicolumn{5}{|c|}{ Received both and spent most of... } \\
\hline Child Credit Rebate & 82.5 & \multirow{2}{*}{0.17} & 62.5 & \multirow{2}{*}{0.86} \\
\hline Reduced Withholding Tax & 73.8 & & 75.3 & \\
\hline
\end{tabular}


Table 7: Estimating the Marginal Propensity to Consume

\begin{tabular}{|c|c|c|c|c|c|c|}
\hline \multirow[b]{3}{*}{ Constant } & \multicolumn{3}{|c|}{ Child Credit Rebate } & \multicolumn{3}{|c|}{ Reduced Withholding Tax } \\
\hline & \multicolumn{2}{|c|}{ Spend now } & \multirow{2}{*}{$\begin{array}{c}\text { Spend within } \\
\text { a year } \\
-0.61 \\
(0.22)\end{array}$} & \multicolumn{2}{|c|}{ Spend now } & \multirow{2}{*}{$\begin{array}{c}\text { Spend within } \\
\text { a year } \\
-0.88 \\
(0.16)\end{array}$} \\
\hline & $\begin{array}{l}-0.88 \\
(0.23)\end{array}$ & $\begin{array}{l}-0.90 \\
(0.23)\end{array}$ & & $\begin{array}{l}-1.16 \\
(0.17)\end{array}$ & $\begin{array}{l}-1.19 \\
(0.17)\end{array}$ & \\
\hline Age: 44 or younger & $\begin{array}{l}-0.36 \\
(0.18)\end{array}$ & $\begin{array}{l}-0.39 \\
(0.19)\end{array}$ & $\begin{array}{l}-0.43 \\
(0.18)\end{array}$ & $\begin{array}{l}-0.14 \\
(0.12)\end{array}$ & $\begin{array}{l}-0.19 \\
(0.13)\end{array}$ & $\begin{array}{c}0.06 \\
(0.12)\end{array}$ \\
\hline Age: 62 or older & $\begin{array}{c}0.31 \\
(0.58)\end{array}$ & $\begin{array}{c}0.33 \\
(0.58)\end{array}$ & $\begin{array}{c}0.17 \\
(0.58)\end{array}$ & $\begin{array}{c}0.58 \\
(0.23)\end{array}$ & $\begin{array}{c}0.58 \\
(0.23)\end{array}$ & $\begin{array}{c}0.49 \\
(0.22)\end{array}$ \\
\hline Own Home & $\begin{array}{c}0.02 \\
(0.19)\end{array}$ & $\begin{array}{c}0.04 \\
(0.20)\end{array}$ & $\begin{array}{l}-0.09 \\
(0.18)\end{array}$ & $\begin{array}{l}-0.29 \\
(0.15)\end{array}$ & $\begin{array}{l}-0.28 \\
(0.15)\end{array}$ & $\begin{array}{l}-0.38 \\
(0.13)\end{array}$ \\
\hline Own Stocks & $\begin{array}{c}0.17 \\
(0.17)\end{array}$ & $\begin{array}{c}0.13 \\
(0.18)\end{array}$ & $\begin{array}{c}0.14 \\
(0.17)\end{array}$ & $\begin{array}{c}0.24 \\
(0.14)\end{array}$ & $\begin{array}{c}0.21 \\
(0.14)\end{array}$ & $\begin{array}{c}0.13 \\
(0.12)\end{array}$ \\
\hline Income: $\$ 30,000$ to $\$ 75,000$ & $\begin{array}{c}0.06 \\
(0.21)\end{array}$ & $\begin{array}{c}0.04 \\
(0.21)\end{array}$ & $\begin{array}{c}0.14 \\
(0.20)\end{array}$ & $\begin{array}{c}0.19 \\
(0.17)\end{array}$ & $\begin{array}{c}0.19 \\
(0.17)\end{array}$ & $\begin{array}{c}0.29 \\
(0.15)\end{array}$ \\
\hline Income: $\$ 75,000$ to $\$ 100,000$ & $\begin{array}{c}0.29 \\
(0.25)\end{array}$ & $\begin{array}{c}0.27 \\
(0.25)\end{array}$ & $\begin{array}{c}0.27 \\
(0.24)\end{array}$ & $\begin{array}{c}0.35 \\
(0.21)\end{array}$ & $\begin{array}{c}0.33 \\
(0.21)\end{array}$ & $\begin{array}{c}0.41 \\
(0.19)\end{array}$ \\
\hline Income: greater than $\$ 100,000$ & $\begin{array}{c}0.29 \\
(0.27)\end{array}$ & $\begin{array}{c}0.20 \\
(0.28)\end{array}$ & $\begin{array}{c}0.14 \\
(0.27)\end{array}$ & $\begin{array}{c}0.49 \\
(0.21)\end{array}$ & $\begin{array}{c}0.41 \\
(0.21)\end{array}$ & $\begin{array}{c}0.57 \\
(0.19)\end{array}$ \\
\hline Expected Real Income Growth & & $\begin{array}{c}0.24 \\
(0.17)\end{array}$ & $\begin{array}{c}0.28 \\
(0.16)\end{array}$ & & $\begin{array}{c}0.25 \\
(0.13)\end{array}$ & $\begin{array}{c}0.13 \\
(0.12)\end{array}$ \\
\hline Log-Likelihood & -202.2 & -201.2 & -224.6 & -338.3 & -336.4 & -421.6 \\
\hline Marginal Propensity to Consume & & & & & & \\
\hline Mean & 0.26 & 0.26 & 0.30 & 0.23 & 0.23 & 0.33 \\
\hline Standard Deviation & 0.05 & 0.06 & 0.06 & 0.06 & 0.06 & 0.07 \\
\hline
\end{tabular}


Table 8: JGTRRA and the Aggregate Spending Response

\begin{tabular}{|c|c|c|c|c|c|c|c|c|c|}
\hline & \multicolumn{3}{|c|}{ Child Credit Rebate } & \multicolumn{3}{|c|}{ Reduced Withholding } & \multicolumn{3}{|c|}{ Total } \\
\hline & Tax Cut & MPC & Spending & Tax Cut & MPC & Spending & Tax Cut & MPC & Spending \\
\hline & \multicolumn{9}{|c|}{$2003 \mathrm{H} 2$} \\
\hline $\begin{array}{l}\text { All Households } \\
\text { Income }(\$ 1,000)\end{array}$ & 15.1 & 0.27 & 4.0 & 20.1 & 0.28 & 5.7 & 35.2 & 0.28 & 9.7 \\
\hline Less than 30 & 1.6 & 0.23 & 0.4 & 0.1 & 0.20 & 0.0 & 1.7 & 0.23 & 0.4 \\
\hline 30 to 75 & 8.7 & 0.24 & 2.1 & 3.1 & 0.22 & 0.7 & 11.9 & 0.23 & 2.8 \\
\hline 75 to 100 & 3.0 & 0.33 & 1.0 & 3.0 & 0.28 & 0.8 & 6.0 & 0.30 & 1.8 \\
\hline \multirow[t]{2}{*}{ Greater than 100} & 1.8 & 0.32 & 0.6 & 13.8 & 0.30 & 4.1 & 15.6 & 0.30 & 4.7 \\
\hline & \multicolumn{9}{|c|}{$2003 H 2 \& 2004 H 1$} \\
\hline $\begin{array}{l}\text { All Households } \\
\text { Income }(\$ 1,000)\end{array}$ & 15.1 & 0.31 & 4.7 & 53.5 & 0.38 & 20.1 & 68.7 & 0.36 & 24.8 \\
\hline Less than 30 & 1.6 & 0.27 & 0.4 & 0.4 & 0.27 & 0.1 & 2.0 & 0.27 & 0.5 \\
\hline 30 to 75 & 8.7 & 0.29 & 2.6 & 8.3 & 0.31 & 2.6 & 17.1 & 0.30 & 5.1 \\
\hline 75 to 100 & 3.0 & 0.37 & 1.1 & 7.9 & 0.37 & 2.9 & 10.9 & 0.37 & 4.1 \\
\hline Greater than 100 & 1.8 & 0.35 & 0.6 & 36.9 & 0.39 & 14.5 & 38.7 & 0.39 & 15.1 \\
\hline
\end{tabular}

Dollar values are in billions of 2000 dollars, deflated using the implicit price deflator for total personal consumption expenditures in the NIPA. Estimates of the tax cut for all households come from the Joint Committee on Taxation, which is then decomposed by income group using the estimated shares of the tax cut imputed using the CPS March 2002 supplement. The total tax cut is the sum of the child credit rebate and reduced withholdings; it does not include the AMT, dividend tax, and marriage penalty relief. MPC's are estimated over the MSC data using the methodology described in the text. Aggregate MPC's (either for all households or for the total tax cut) are defined as the ratio of the aggregate spending response to the aggregate tax cut. 